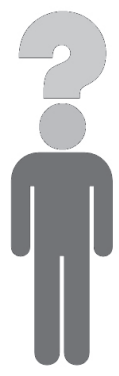

Społeczeństwo odpowiedzialne? O aspektach odpowiedzialności

w życiu społecznym jednostek, red. K. Cikała, W. B. Zieliński, Kraków 2015, s. 152-163

DOI: http://dx.doi.org/10.15633/9788374384254.14

Magdalena Tendera

\title{
„ETYKA” RASY JAKO WYBRANE MECHANIZMY WEWNĄTRZRASOWE A KONTROWERSYJNY CHARAKTER KATEGORII RAS LUDZKICH
}

Kategoria ras ludzkich od wielu dziesięcioleci pozostaje w centrum zainteresowania wielu nauk, zwłaszcza społecznych, humanistycznych i biologicznych. Wszystkie właściwie społeczeństwa posiadają to pojęcie w swoim słowniku, choć desygnaty tych pojęć znacznie różnią się od siebie. Ludzkie rasy typizowane są w rozmaity sposób i w istocie tzw. podziały rasowe desygnują typologie różnic międzyludzkich w różnych kulturach. Podział rasowy w historii rozwoju ludzkości cieszy się niestety głównie niechlubną sławą, ponieważ oficjalne uznanie różnic w obrębie gatunku sprzyja budowaniu antagonizmów międzyrasowych i wykorzystywany bywa do manipulacji politycznych i jako pretekst do eksterminacji ${ }^{1}$. Proponowany typ etyki to zbiór zasad regulujących moralność w interakcjach międzyrasowych wyprowadzony z zachowań o podłożu socjo-biologicznym i poznawczym generującym etyczne zachowania wobec przedstawicieli własnej rasy będące odruchami i pozostające poza bezpośrednią kontrolą podmiotu. W tym artykule mam zamiar skoncentrować się na drugim z tych fenomenów. Nie oznacza on nurtu naukowego, lecz coś na wzór wewnątrzrasowej i wewnątrzgatunkowej regulacji mającej sprzyjać przetrwaniu każdej z ras osobno; „etyczność” taka pozwala się badać poprzez metody obserwacji czy eksperyment i dlatego - dla odróżnienia jej od filozofii - omawianą poniżej grupę zjawisk poddających się badaniom empirycznym określę „etyką" rasy.

1 Zob. K. A. Appiah, A. Gutman A., Color conscious. The political morality of race, Princeton 1996. 
Koncepcje antropologiczne rasy najpierw wraz z wybuchem popularności ewolucjonizmu zdominowały myślenie naukowe, następnie szybko je wycofano w dyskursu naukowego ${ }^{2}$, a teraz zaczyna się już dużo bardziej krytyczna refleksja nad nieusuwalnością tej kategorii z życia społecznego jako osiowej kategorii kulturowej.

Wiadome jest, że aby rozmaite zachowania społeczne mogły pełnić swoją funkcję regulacyjną życia społecznego, wymagane jest wcześniejsze przyporządkowanie drugiego człowieka jakiejś kategorii (rasy, płci, wieku, etc.), co zaś zakłada operowanie gotową klasyfikacją ludzi z uwagi na cechy płci, koloru skóry etc. Ludzie dostrzegają fakt, że różnią się między sobą lub są do siebie podobni i różnice te oraz podobieństwa w rozmaity sposób są organizowane. Dostrzeżenie istnienia podobieństw skutkuje $w$ większym stopniem kooperacji w działaniach, sympatii w deklaracjach, interakcjach społecznych, podzielaniu podobnych systemów wartościowania. Świadomości podobieństw i różnic sprzyja zjawisko transmisji międzypokoleniowej kultury, które automatycznie selekcjonuje działania społeczne. Z drugiej strony, jak pisze Antonina Kłoskowska, przynależności: kulturowa i narodowa są cechami manipulowanymi. Przynależności takie dają się w różnoraki sposób manipulować: można je zerwać, wzmocnić lub osłabić3. Argumenty te wyraźnie świadczą, że świadomość rasowa jest wytworem kulturowym i ukształtowała się jako cecha organizująca rzeczywistość.

Nauka w momencie odkrycia, że brak jest podłoża biologicznego dla klasyfikacji ras, bardzo szybko zminimalizowała znaczenie tej kategorii do artefaktu kulturowego. Już w „dziewiętnastowiecznej antropologii pojęcie rasy było gorąco dyskutowane zarówno wewnątrz dyscypliny, jaki z przedstawicielami innych nauk"4. Jednak zabiegi te nie znajdują odbicia w praktyce społecznych interakcji - klasyfikacje rasowe są powszechnie stosowane we wszystkich częściach globu.

Rasę ludzką jako zagadnienie naukowe można rozpatrywać, stosując różne podejścia:

- Antropologiczny punkt widzenia - pomimo, iż odkrycie „Innego” jako uświadomienie sobie zróżnicowania człowieka w obrębie własnej rasy, człowieka

2 Zob. G. Kubica, Antropologiczny dyskurs rasowy: jego twórcy i dekonstruktorzy, [w:] W krainie metarefleksji. Księga poświęcona profesorowi Czesławowi Robotyckiemu, red. J. Barański, M. Golonka-Czajkowska, A. Niedźwiedź, Kraków (w druku), s. 94-117.

3 Zob. A. Kłoskowska, Kultury narodowe u korzeni, Warszawa 2012.

4 G. Kubica, Antropologiczny dyskurs rasowy..., dz. cyt., s. 95. 
różniącego się od nas jakimiś elementami było związane nie tylko z epoką wzrastającej mobilności, postępu technologicznego, ale także z powstaniem pewnego aparatu myślowego czy pojęciowego pozwalającego na uchwycenie i opisanie zjawisk rasowych. Wydaje się, że niezbędny był też odpowiedni poziom samoświadomości społeczeństwa europejskiego. To, że istnieją inne ludy, kultury i języki, wiadomo było już od dawna. To ewolucjonizm w nauce przesądził, że postawiono pytanie o to, czy mechanizm różnicowania się ludzi i kultur jest tożsamy z ewolucją społeczną. W ten sposób możliwy stał się dyskurs rasowy w nauce ${ }^{5}$. Zagadnienie to było istotne zwłaszcza w momencie, w którym rodziła się antropologia społeczna. To odkrycie innego człowieka, innych kultur, czyli dostrzeżenie faktu, że ludzie fizycznie i w zachowaniu różnią się od siebie, pchnęło Europejczyków w stronę coraz bardziej usystematyzowanych badań. Badania te najpierw polegały na niezorganizowanych formach zbierania danych, aby potem stać się działaniem planowanym i systemowym. Zatem przeszły z formy ad hoc, czyli nagłych badań terenowych, aby potem dzięki Bronisławowi Malinowskiemu stać się metodą intensywnych badań terenowych, a więc działaniem zamierzonym, celowym, systemowym i długotrwałym.

- Społeczne i kulturowe - zwłaszcza w takim wymiarze, w jakim kategoria rasy ma znaczenie dla budowania rozmaitych stratyfikacji społecznych, podziałów, ale i tym samym sojuszy i różnych form kooperacji, podział na rasy jest aktywnie podtrzymywany ${ }^{6}$. Społeczne i kulturowe znaczenie rasy jest też silne związane z problematyką rasizmu, zatem nietolerancji z uwagi na pochodzenie rasowe. Istotne jest także, że podtrzymywanie zróżnicowania etnicznego ma dużo zasadniczych korzyści i pozwala realizować cele wyznaczone przez mniejszość. Niektórzy autorzy ${ }^{7}$ mówią wprost, że tam, gdzie istnieje wysoki poziom zróżnicowania, nie jest możliwy wysoki poziom zaufania społecznego, i że zjawiska te są nie do pogodzenia.

- Poznawcze - podział na rasy ludzkie jako jeden ze sposobów porządkowania rzeczywistości. Podział na rasy jest zdecydowanie formą organiza-

Zob. tamże.

6 J. Ogbu, Minority education in comparative perspective, „Journal of Negro Education” vol. 59 (1990), s. 45-57.

7 T. J. Rudolph, E. Popp, Race, environment, and interracial trust, „The Journal of Politics” vol. 72 (2010) no. 1, s. 74-89. 
cji zróżnicowanej rzeczywistości w określone kategorie. Na różnorodność np. kolorów skóry nakładane są podziały ich typów po to, aby wśród nich zaprowadzić ład i - wreszcie - aby móc selekcjonować działania społeczne tak, by były bardziej efektywne przystosowawczo albo w ogóle - jakkolwiek logiczne i możliwe do systematyzacji. Antropologia od bardzo wielu lat zajmuje się różnego typu podziałami, klasyfikacjami i budowaniem schematów poznawczych.

Georges Cuvier (1769 - 1832) podzielił ludzi na następujące rasy ${ }^{8}$ :

- białą,

- czarną,

- żółtą.

Podział ten przejęli ewolucjoniści. Sam Cuvier nie był ewolucjonistą - jednak rodząca się wraz z ewolucjonizmem w naukach społecznych antropologia uznała różnice kolorów skóry za różnice ewolucyjne. Podział ten był prosty i kuszący.

Nie jest to jedyna typologia - próbowano także klasyfikować rasy europejskie: „Przyzwyczailiśmy się mówić «Skandynawczyk» na kogoś wysokiego, z blond włosami i z niebieskimi oczami, «południowy Włoch» mówimy o kimś niskim, krępym i ciemnookim; typ cygański jest średniego wzrostu, z niebieskimi lub szarymi oczami i szeroką twarzą i prostymi włosami ${ }^{9}$, „jesteśmy skłonni budować typy idealne w oparciu o nasze codzienne doświadczenie, są one wyabstrahowane z kombinacji najczęstszych form spotykanych lokalnie i zapominamy, że jest mnóstwo jednostek, które nie odpowiadają temu typowi"10. Na tym przykładzie widać z resztą, jak daleko próbowano specjalizować kategorię rasy.

Cytowany tutaj Franz Boas (1858-1942) w taki sposób definiuje rasę: „w mowie potocznej, gdy używamy pojęcia rasy, mamy na myśli grupę ludzi, którzy powszechnie posiadają określone fizyczne i prawdopodobnie mentalne cechy"11. Antropolog ten był również autorem badań nad związkiem środowiska z kształtem czaszki. W badaniach swoich wykazał, co z resztą było jego zamiarem, że

średni obwód głowy potomków imigrantów typów (etnicznych - przyp. M. T.) z Europy Wschodniej jest bardziej wydłużony, a tych z Europy Zachodniej bardziej zaokrą-

\footnotetext{
8 Zob. Antropologia fizyczna, red. A. Malinowski, Warszawa-Poznań 1980.

9 F. Boas, Race, language and culture, New York, 1966, s. 4.

10 Tamże, s. 4.

11 Tamże.
} 
glony niż ich rodziców. Dane te zostały uzyskane częściowo metodą generalizacji, częściowo poprzez porównanie pomiędzy rodzicami i ich dziećmi ${ }^{12}$.

Boas prowadził badania, których celem było udowodnienie, iż cechy fizyczne są wytworem środowiska do tego stopnia, że jeśli para zmienia miejsce zamieszkania, to ich dziecko szybko nabędzie cech fizycznych - dokładnie kształtu i wymiarów czaszki - które są efektem lepszego przystosowania do nowego środowiska. Zmiany te, w założeniu Boasa, miały by zatem być natychmiastowe:

proporcje ciała zmieniają się wraz z wykonywanym zawodem. Kształt dłoni pracownika fizycznego jest inny niż kształt dłoni muzyka zawodowego. Zmiany w kształcie czaszki, jakie są obserwowane (u imigrantów - przyp. M. T.), są analogiczne do tych, jakie można zaobserwować u zwierząt żyjących w różnych warunkach, pomiędzy Iwami, które rodzą się w niewoli, lub pomiędzy szczurami, u których wprowadza się różną dietę. Zasięg, w jakim geograficzne i społeczne środowisko może mieć wpływ na zmianą formy ciała, nie jest do końca znany, ale wpływ czynników zewnętrznych musi być brany pod rozwagę przy porównywaniu typów ludzkich ${ }^{13}$.

I dodaje: „są powody organiczne, dla których jednostki różnią się między sobą w zachowaniach mentalnych"14.

Badania te - wątpliwe od samego początku - miały niezwykle silny oddźwięk przez następne sto lat. Nie tak dawno - w perspektywie czasu dzielącego nas od badań Boasa - ukazał się artykuł Corey’a Sparksa i Richarda Jantza zatytułowany $A$ reassessment of human cranial plasticity. Boas revisited. Badacze ci powtórzyli badania Boasa na grupie 8000 osób reprezentujących różne grupy etniczne migrantów z Europy. Wnioski z badań wskazywały jednoznacznie, że zróżnicowanie anatomiczne jest dziedziczone genetyczne w rodzinach, zaś ewentualne inne znaczące różnice są cechą poszczególnych grup etnicznych ${ }^{15}$.

Należy jednak zaznaczyć, że Boas walczył z przejawami rasizmu, nierównością i segregacją rasową. Chciał on jednak udowodnić tezę, że ludzka rasa jest efektem czynników środowiska, dlatego że taki wynik badań jednoznacznie zamknąłby spekulacje na temat tego, że zróżnicowanie cech fizycznych jest skut-

12 Tamże, s. 76.

13 Tamże, s. 8.

14 Tamże, s. 9.

15 C. S. Sparks, R. L. Jantz, A reassessment of human cranial plasticity. Boas revisited, „Proceedings of the National Academy of Sciences", November 12 (2002), s. 14636-14639. 
kiem zróżnicowania genetycznego ras. Należy także przypomnieć, że pomimo tego faktu dokonania naukowe Franza Boasa na polu antropologii są ogromne.

Rasa nie była głównym przedmiotem zainteresowań Raymonda Firtha, jednak kilka jego myśli doskonale oddaje trendy epoki wczesnej antropologii:

[...] antropolog zwykle zgodzi się ze mną; będzie mówił o ludziach w kategoriach koloru skóry o rasach: białej, ciemnej i żółtej. Szczegółowe charakterystyki ras można również podać w odniesieniu do skóry, włosów, koloru oczu, struktury włosa, reakcji krwi, rozmiarów i proporcji głowy i ciała oraz innych liczne fizycznych cech charakterystycznych dla grup ludzi żyjących w różnych częściach świata ${ }^{16}$;

tam, gdzie antagonizm rasowy występuje, w istocie jest to prawdziwy społeczny antagonizm, tego samego rodzaju, co rozłamy pomiędzy różnymi grupami narodowy$\mathrm{mi}$. Jest on ufundowany nie na różnicach w poziomie mentalnym pomiędzy rasami jako takimi, ale na różnicach ekonomicznych i interesach społecznych różnego rodzaju. Kolor skóry i inne fizyczne cechy widoczne lub wnioskowane na podstawie pochodzenia nie są faktyczną podstawą do antagonizmów; są raczej po prostu wygodnym i arbitralnym ich symbolem ${ }^{17}$.

\section{Ludwik Krzywicki zwraca uwagę, że typy rasowe są}

typami abstrakcyjnymi, tj, istniejącymi jedynie na papierze i w rzeczywistości spotykanymi z rzadka i tylko w postaci zbliżonej. Nie godzi się więc zapominać w ciągu dalszego wykładu, iż typy rasowe, o których będziemy mówili, są kategoriami poniekąd sztucznymi ${ }^{18}$.

Sztucznymi w takim sensie, że wytworzonymi w istocie poza naturą czy biologią. Nie istnieją żadne biologiczne przesłanki na istnienie ras ludzkich, czystość fenotypów jest raczej konstruktem kulturowym niż faktem biologicznym, zaś - jak pisał Firth - „czystość rasy jest konceptem politycznej propagandy, nie naukowego opisu"19. Jeżeli należy w tym punkcie absolutnie zgodzić się z Boasem, to w kolejnym należy wyraźnie powiedzieć, czym rasa jest. Wydaje się, że w takim razie rasa jest kulturowym konstruktem oddającym podstawowe zróżnicowanie $\mathrm{w}$ ob-

16 R. Firth R., Human types, London 1938, s. 13.

17 Tamże.

18 L. Krzywicki, Kurs systematyczny antropologii. Rasy fizyczne, [w:] tegoż, Dzieła, t. 7, Warszawa 1969, s. 333.

19 R. Firth R., Human types, London 1938, s. 21. 
rębie gatunku ludzkiego. Podstawowe w tym sensie, że od razu dostrzegalne. O ile nie możemy wskazać poszczególnych fenotypów rasowych, o tyle również nie możemy powiedzieć, że wszyscy ludzie na Ziemi są identyczni fizycznie. Kultura wykształciła pewne schematy i nałożyła je na zróżnicowanie biologiczne i społeczne. Pozwalają one ludziom od wieków orientować się w rzeczywistości społecznej. To jest właśnie rasa. Wiemy, że konstrukt ten jest kulturowy, ponieważ wszystkie właściwie społeczeństwa w jakiś sposób dzielą ludzi na rasy, a podziały te są tak rozmaite, że nie mogą świadczyć o uniwersalności stosowanego klucza.

To, że rasa jest konstruktem społecznym i nie jest biologicznie istotna, oznacza, że podziały rasowe nie stanowią o żadnych granicach zdolności intelektualnych, umiejętności, nie korelują w żaden istotny sposób ze stanem zdrowia, wyposażeniem genetycznym, cechami mentalnymi. To, co nazywamy rasą, jest w bardzo luźny sposób powiązane z poszczególnymi społecznościami ludzkimi, które rozwijały się na różnych obszarach świata, nieco zmieniając swoje cechy. Te różnice nie znajdują odbicia w zróżnicowaniu genetycznym, co oznacza, że nie można powiedzieć, że za zróżnicowanie w obrębie gatunku ludzkiego daje się w wymierny sposób przełożyć na wyposażenie genetyczne ${ }^{20}$.

Rozróżnienia etniczne często zbiegają się z podziałami terytorialnymi w wieloetnicznych społeczeństwach i są odzwierciedleniem społecznych konstruktów dotyczących tożsamości rasowej. Szeroko uznawane różnice rasowe mogą wzmacniać samoidentyfikację członków różnych grup i rozróżnienia międzygrupowe. Podobnie gdy interakcje pomiędzy grupami są ograniczone i warunkowane przez podziały terytorialne, międzygrupowe różnice zyskują na silne. Nacisk na interakcje wewnątrzgrupowe prowadzi do wzajemnego ignorowania się członków różnych grup ${ }^{21}$.

Można zatem spojrzeć na konstrukcję rasy jak na reprezentację poznawczą mającą cechy strukturalne i ulegającą przekształceniom strukturalnym. Przekształcenia te są rozumiane jako aktywne mechanizmy przystosowania się danej kultury do zmiennej rzeczywistości społecznej. Kultura jest tutaj rozumiana jako wytwór procesów poznawczych człowieka - zbiór reprezentacjii ${ }^{22}$ różny

20 Zob. O. K. Obasogie, Playing the gene cards? A report on race and human technology, preface D. Roberts, Oakland 2009, http://www.geneticsandsociety.org/downloads/complete_PTGC.pdf (16.05.2014), s. 1-95.

21 J. M. Sanders, Ethnic boundaries and identity in plural societies, „Annual Review of Sociology” vol. 28 (2002), s. 328.

22 A. K. Romney, J. P. Boyd, C. C. Moore, W. H. Batchelder, T. J. Brazill, Culture as shared cognitive representations, „,Proceedings of the National Academy of Sciences. Anthropology” vol. 93 (1996), s. 4699-4705. 
dla różnych społeczeństw i jednostek, bo determinowany przedmiotem i procesem poznania, które różnią się między sobą w uwagi na wymogi - chociażby-środowiska naturalnego. W praktyce liczba czynników mających wpływ na konstrukty rasy jest bardzo duża, istotne $z$ nich są konflikty na tle rasowym i etnicznym, które sprawiają, że konstrukty są „wyposażane” w cechy jednoznacznie negatywne. Od bardzo dawna w naukach społecznych - w tym w psychologii - na prawach aksjomatu funkcjonuje założenie, że akt postrzegania nie jest prostą czynnością mechaniczną i że to pozornie proste działanie jest w istocie kształtowane przez rozmaite zmienne: wartości, doświadczenie, stereotypy, stany emocjonalne etc. ${ }^{23}$.

Jak podaje Encyclopedia of race and racism (2008),

termin rasa został przejęty przez biologów humanistycznych z biologii ogólnej i oznacza po prostu lokalny rodzaj zróżnicowania w obrębie gatunku, stosowany zwłaszcza do tych pospolitych roślin i zwierząt, które były w centrum zainteresowania wczesnych naturalistów i filozofów. [...] Wraz z odkryciem genów na początku dwudziestego wieku gatunek został zdefiniowany bardziej precyzyjnie jako grupa, która ma wspólne wyposażenie genetyczne, swobodnie wymienia w swoim obrębie materiał genetyczny, ale już nie z innymi gatunkami. Rasa zatem może stanowić pomniejszą formę adaptacji do lokalnych warunków w obrębie gatunku²4.

Ponieważ jednak kategoria rasy jest niezwykle problematyczna, w dyskursie naukowym od dawna postuluje się odchodzenie od jej używania na rzecz pojęcia etniczności i grup społecznych. Sprawa ta wydaje się jednak bardzo skomplikowana. Należy zaznaczyć, że oprócz tego, że podziały rasowe i etniczne sprzyjają tworzeniu się podziałów społecznych, należy wskazać kulturowe pożytki z utrzymywania tych kategorii jako aktywnie manifestowanych społecznych odrębności. Korzyści z podtrzymywania różnić rasowych i etnicznych służą osiąganiu celów mniejszości ${ }^{25}$. Jakie są to cele? Na przykład w przypadku mniejszości imigrantów w danym regionie jest to możliwość uzyskania różnych praw cywilnych, przywilejów politycznych czy praw dla uchodźców. Utrzymywanie statusu odrębnej grupy może pomóc w wbudowaniu sytuacji dobrobytu tym grupom, którym z różnych powodów nie udało się tego zrobić u siebie, w rodzimym kra-

23 Zob. M. L. de Fleur, F. R. Westie, The interpretation of interracial situations: an experiment in social perceptron, „Social Forces” vol. 38 (1959) no. 1, s. 17-23.

24 Race, [w:] Encyclopedia of race and racism, Detroit 2008, s. XI.

25 Zob. J. Ogbu, Minority education in comparative perspective, dz. cyt., s. 45-57. 
ju. Często jest to łatwiejszy dostęp do służby zdrowia, edukacji pomimo barier językowych.

Co więcej, samo wyprowadzenie podziałów i typologii czy zlokalizowanie ich i zdefiniowanie oraz staranne opisanie jest dopiero początkiem rozpoznania różnych mechanizmów kulturowych. Pytania, które się wtedy pojawiają, dotyczą relacji zachodzących pomiędzy rozmaitymi grupami rasowymi i etnicznymi. To te zjawiska, konsekwencje podziałów, stanowią wielokrotnie o problemach społecznych. W tym momencie coraz więcej uwagi poświęca się mechanizmom pojawiania się i utrzymywania wzajemnej wrogości, agresji czy też sympatii i altruizmu pomiędzy grupami.

Prowadzone były badania nad zaufaniem społecznym w multikulturowych społeczeństwach. Coraz większa ilość danych wskazuje, że zróżnicowanie rasowe i etniczne, które uchodzi za sztandarową "cnotę" liberalnych społeczeństw, $w$ istocie stoi na przeszkodzie $w$ rozwoju wysokiego stopnia zaufania społecznego ich obywateli. W kolejnej fazie badane są zatem różne formy wspólnot ${ }^{26}$ oraz typy relacji i ich układów strukturalnych. Celem tych badań jest zrozumienie schematów funkcjonowania tych społeczeństw, w których pomimo wysokiego poziomu zróżnicowania utrzymuje się też wysoki poziom zaufania społecznego. Zgodnie z wynikami badań prowadzonych przez Rudolpha i Poppa wizja społeczeństwa wielorasowego i wielokulturowego wyklucza wysoki stopień wzajemnego zaufania mieszkańców wielorasowych osiedli27. Niski stopień zaufania przejawia się w zwiększonym poziomie ogólnego lęku, wzajemnej podejrzliwości i słabych więziach sąsiedzkich.

Niezwykle interesujące badania w kontekście zróżnicowania rasowego prowadzone były nad empatią. Replikowane kilkakrotnie eksperymenty prowadzone przy pomocy metody obrazowania mózgu pokazały różnicę w poziomie empatii względem rasy swojej oraz odmiennej niż swoja na korzyść tej pierwszej. Xu, Zuo, Wang i $\mathrm{Han}^{28}$ studentom Chińczykom oraz reprezentantom tzw. rasy kaukaskiej pokazywali film, na którym osoby jednej i drugiej rasy poddawano działaniu bodźca bolesnego i bezbolesnego (były kłute w twarz igłą

26 Zob. T. J. Rudolph, E. Popp, Race, environment, and interracial trust, „The Journal of Politics” vol. $72(2010)$ 1, s. 74-89.

27 Zob. tamże.

28 X. Xu, X. Zuo, X. Wang, S. Han, Do you feel my pain? Racial group membership modulates empathic neural responses, „The Journal of Neuroscience” 29 (2009) 26, s. 8525-8529. 
lub patyczkiem kosmetycznym). Badana była reakcja mózgu na widok bolesnego i bezbolesnego bodźca aplikowanego przedstawicielowi swojej i innej rasy. W przypadku obserwowania przedstawiciela własnej rasy poddawanego działaniu bodźca bolesnego znacznie bardziej niż w przypadku reprezentanta rasy drugiej aktywizował się płat czołowy odpowiedzialny za współodczuwanie. Zależność taka miała miejsce w przypadku przedstawicieli obu ras, ośrodki współczucia dużo silniej aktywizowały się na widok przedstawiciela własnej rasy niż przedstawiciela rasy innej. Dodatkowo ośrodek ten nie aktywizował się w przypadku, gdy osoba należąca do „swojej” rasy kłuta była w twarz patyczkiem kosmetycznym.

Istnieje wiele badań opisujących skutki negatywnych i pozytywnych konotacji kolorów dla życia społecznego. Można rozważać, na ile i w jakich warunkach wyniki tych badań mogą być ekstrapolowane na sytuacje społeczne. Longshore i Bielin ${ }^{29}$ przywołują badania różnych autorów. W jednym z przypadków przywołanych badaniom poddane zostały dzieci rasy białej w wieku przedszkolnym. Pokazywano im różne przedmioty i proszono o opisanie je jako pozytywne i negatywne, a następnie o umieszczanie tych przedmiotów w białych lub czarnych pudełkach. Okazało się, że dzieci w znakomitej większości umieszczały negatywnie ocenione przedmioty w czarnym, a pozytywnie ocenione w białym pudełku. Autorzy przywołują także wiele zjawisk językowych, w których kolor czarny ma jednoznacznie negatywne korelacje. W języku polskim synonimami takich zjawisk są określenia: „czarna owca”, „czarna lista”, „czarne myśli” i wiele innych. Ich przeciwieństwami, przykładami pozytywnego skorelowania cech z kolorem białym, są takie określenia, jak: „biały kruk”, „białe kłamstwo” czy „rycerz na białym koniu” symbolizujący spełnienie ideału mężczyzny w oczach kobiety. Często wskazuje się także, że działania społeczne uzyskują racjonalizację poprzez znaczenie koloru skóry - biały oznacza czystość, czarny zaś brud i zmazę ${ }^{30}$.

W dyskursie naukowym obszaru antropologii społecznej, jak już wspomniano, kategoria rasy jest bardzo sporna, często postuluje się zastępowanie jej kategorią grupy etnicznej czy grupy społecznejej $\mathrm{i}$ bada to, w jaki sposób sami

29 Zob. D. Longshore, R. Bielin, Interracial behavior in the prisoner's dilemma: the effect of color connotations, „Journal of Black Studies” vol. 11 (1980), s. 105-120.

30 Tamże.

31 Zob. G. Kubica, Antropologiczny dyskurs rasowy..., dz. cyt., s. 94-117. 
przedstawiciele nauki rozumieją rasę ${ }^{32}$. Jednocześnie wydaje się, że ten postulat świata nauki może okazać się praktycznie niewykonalny. Pierwszym argumentem, który można wysunąć na rzecz obrony kategorii rasy, jest jej trwałość i nieusuwalność ze świadomości społecznej. Przytoczone powyżej badania nasuwają wniosek, że jeżeli nie istniałaby kategoria rasy ludzkiej, to po prostu należałoby ją stworzyć. Desygnuje ona podstawowy podział stosowany w procesach poznawczych i bez jej istnienia trudno byłoby posługiwać się innymi kategoriami, np. dyskutować na temat zróżnicowania w obrębie gatunku ludzkiego. Zróżnicowanie takowe istnieje, ponieważ różnice $w$ kolorze skóry są natychmiast dostrzegalne i implikują wniosek, że ludzie nie są tacy sami.

Podział poznawczy na rasy istnieje i ma znaczenie w kontakcie międzykulturowym. Konstrukt rasy może być zastępowalny przez etniczność lub kategorię grupy społecznej - mają one podobne funkcje, ale zwykle dotyczą innych typów cech. Generalnie rasa dotyczy cech podstawowych takich jak: kolor skóry, wysokość ciała, struktura włosa, kształt oczu. Kategoria etniczności bywa bardziej wyczulona na język, zwyczaj, kulturę, rytuał i rozmaite fizyczne artefakty jako przedmioty funkcjonalne i estetyczne. Wartościowy wydaje się natomiast postulat badania tego, w jaki sposób kategorie rasy są konstruowane w różnych kulturach i na różnych obszarach świata, z jakich cech się składają i jaki mają wpływ na życie.

Jednocześnie należy powtórzyć, że każda różnica, postrzegana czy wyimaginowana, może być przyczyną dyskryminacji. Usuwanie kategorii rasowych ze słownika nie usunie problemów społecznych ani istniejących podziałów. Sprawi jedynie, że znajdą one inną nazwę. I, co najważniejsze, istnienie różnic rasowych nie usprawiedliwia rasizmu, tak jak zróżnicowanie ze względu na płeć nie usprawiedliwia seksizmu - są to zjawiska uboczne wobec różnicowania w obrębie gatunku ludzkiego.

Idealną sytuacją byłaby fuzja podstawowych systemów etycznych (zwłaszcza etyka różnic kulturowych) z opisaną tutaj „etyką” rasy jako systemu myślowego opartego na zasadach działania ludzi jako jednostek nie tylko społecznych, ale i biologicznych. Człowiek postrzega otaczającą go rzeczywistość, różnicuje dużo szybciej, niż jest w stanie dokonać świadomej refleksji nad swoim zachowaniem. Ważne jest zatem prowadzenie badań nad wzajemnymi powiązaniami kultury, różnic rasowych i procesów poznania.

32 L. Lieberman, R. E. Hampton, A. Littlefield, G. Hallead, Race in biology and anthropology: a study of college texts and professors, „Journal of Research in Science Teaching” vol. 29 (1992) 3, s. 301-321. 


\section{Bibliografia}

Appiah K. A., Gutman A., Color conscious. The political morality of race, Princeton 1996.

Boas F., Race, language and culture, New York, 1966.

De Fleur M. L., Westie F. R., The interpretation of interracial situations: an experiment in social perceptron, „Social Forces” vol. 38 (1959) no. 1, s. 17-23.

Firth R., Human types, London 1938.

Kłoskowska A., Kultury narodowe u korzeni, Warszawa 2012.

Krzywicki L., Kurs systematyczny antropologii. Rasy fizyczne, [w:] L. Krzywicki, Dzieła, t. 7, Warszawa 1969.

Kubica G., Antropologiczny dyskurs rasowy: jego twórcy i dekonstruktorzy, [w:] W krainie metarefleksji. Księga poświęcona profesorowi Czesławowi Robotyckiemu, red. J. Barański, M. Golonka-Czajkowska, A. Niedźwiedź, Kraków (w druku), s. 94-117.

Lieberman L., Hampton R. E., Littlefield A., Hallead G., Race in biology and anthropology: a study of college texts and professors, „Journal of Research in Science Teaching” vol. 29 (1992) 3, s. 301-321.

Obasogie O. K., Playing the gene cards? A report on race and human technology, preface D. Roberts, Oakland 2009.

Ogbu J., Minority education in comparative perspective, „Journal of Negro Education” vol. 59 (1990), s. 45-57.

Romney A. K., Boyd J. P., Moore C. C., Batchelder W. H., Brazill T. J., Culture as shared cognitive representations, „Proceedings of the National Academy of Sciences. Anthropology" vol. 93 (1996), s. 4699-4705.

Rudolph T. J., Popp E., Race, environment, and interracial trust, "The Journal of Politics" vol. 72 (2010) 1, s. 74-89.

Sanders J. M., Ethnic boundaries and identity in plural societies, „Annual Review of Sociology" vol. 28 (2002), s. 327-357.

Sparks C. S., Jantz R. L., A reassessment of human cranial plasticity. Boas revisited, „Proceedings of the National Academy of Sciences”, November 12 (2002), s. 1463614639.

Xu X., Zuo X., Wang X, Han S., Do you feel my pain? Racial group membership modulates empathic neural responses, „The Journal of Neuroscience” 29 (2009) 26, s. 8525-8529. 